\title{
Resenha
}

\section{O OITAVO HÁBITO: DA EFICÁCIA À GRANDEZA}

(Covey, Stephen R. O oitavo hábito.Rio de Janeiro: Campus, 2004)

André Luiz de Albuquerque Farias (1)

O Oitavo Hábito, é um livro interessante, haja vista tratar-se de um assunto relacionado a um Best Seller mundialmente famoso "Os 7 hábitos das pessoas muito eficazes", do mesmo autor. Revelase um livro de auto-ajuda um pouco diferente, cuja missão nos parece ser, influenciar pessoas na descoberta do seu potencial interior. Talvez mais do que isso, uma espécie de passo-a-passo para se conseguir uma melhor performance, em termos de aprimoramento do nosso caráter, como seres humanos.

As pessoas parecem ter uma natural atenção para assuntos que prometam melhorar sua paz de espírito, seus relacionamentos e seu bem-estar de uma maneira geral. Neste sentido, o Oitavo Hábito tenta ser este caminho.

Ele nos ensina sobre de que forma poderemos resolver situações como: manutenção de hábitos saudáveis de vida; relacionamentos mais eficazes e duradouros; obter mais confiança em si mesmo; cultivar valores humanos e, conviver melhor com as adversidades. O livro se desenvolve em capítulos, a saber:

No primeiro, nos fala sobre a dor e as nossas principais dificuldades em assumir os diversos papéis sociais, bem como a sensação de vazio sentido à partir da vivência desses papéis; No segundo ressalta o problema, que estaria na raiz da dor. Este seria proveniente da industrialização e da formas de trabalho dominante da era industrial. A coisificação do homem. O valor de ter, sobrepondo-se ao ser e toda a mecanização nos relacionamentos, ancorados no paradigma mecanicista da era industrial; O capítulo 3 nos reporta a uma possível solução, que seria a escuta de uma voz interior e de todo um investimento no sentido de compreendê-la. Um processo gradual, que o autor denomina de Pessoa Integral. 
O capítulo 4 está relacionado ao encontro desta voz interior, que o autor reporta como a chave de acesso aos principais dons humanos inatos: a liberdade de escolha, os princípios universais e nossas quatro inteligências humanas - corpo, mente, coração e espírito. Encontrar a voz interior seria então um mergulho e um experienciar a própria sabedoria intuitiva. Dessa forma, o indivíduo se tornaria melhor instrumentalizado para fazer suas escolhas e julgamentos.

No capítulo 5 nos orienta sobre a expressão da nossa voz interior, através da visão, da disciplina, da paixão e da consciência. Seria esta a representação mais elevada de nossa voz. Neste capítulo, lança mão de exemplos do cotidiano, de pessoas que influenciaram o mundo para o bem, através de suas vozes interiores. O autor reconhece que essas pessoas possuíam esses traços da voz interior, principalmente a consciência.

No capítulo 6, o autor nos motiva a tentar influenciar os outros a encontrarem suas vozes interiores. E assim, desafiar nossa liderança pessoal, como forma de exercitar nosso crescimento pessoal. Nos orienta como ajudar as pessoas a encontrarem o seu caminho, o caminho do bem-estar e da felicidade pessoal.

O capítulo 7 nos fala que a voz da influência, pode ser algo compensador para toda a humanidade. É a partir dessa voz que as mudanças sustentáveis começam a surgir, inicialmente em seu círculo de influência, posteriormente tomando maiores proporções. O trabalho solidário ajuda a compensar as fraquezas do outro, além de promover uma real influencia, para que outros venham também a se motivarem nesta direção.

No capítulo 8 trata sobre a voz da confiabilidade - modelando o caráter e a competência. Neste caso, nos informa que, a confiança mútua gerada por todo esse processo seria a chave para as mudanças verdadeiramente duráveis. Que a confiança nasce à partir do caráter e da competência percebidos no outro. E que esta mesma confiança é que une, agrega valores, solidifica amizades e, promove a segurança nos relacionamentos. Essas características são fortes influenciadores de uma real melhoria da auto-estima.

No capítulo 9 ressalta a influência da Voz na rapidez com que se instala a confiança. Que quando há confiança, as coisas acontecem de forma natural e rápida. Assim, a percepção de "poder fazer acontecer" seria mais motivadora a novas investidas proativas, melhorando-se a performance individual e grupal.

No capítulo 10, nos revela sobre a busca de uma terceira alternativa. Que muitas vezes, ao lidar com a complexidade humana, surgem conflitos e diferenças, que necessitam serem pensadas de uma forma apropriada, muitas vezes necessitando de uma alternativa nova, especialmente pensada para o caso. O processo de modelagem do caráter pode ser demorado e instável. Neste caso, o indivíduo há que ter competência e confiança para lidar com as novas alternativas que possam resolver o conflito.

O capítulo 11 nos fala sobre a importância da descoberta de caminhos para se chegar a visão, valores e estratégias compartilhadas apropriadas. Neste caso, há que haver um investimento na 
modelagem. Neste caso, o autor concebe alguns princípios existentes por trás da descoberta de caminhos para alcançar objetivos compartilhados.

O capítulo 12 fala sobre alinhar objetivos e sistemas para obtenção dos resultados esperados. Neste ponto há uma necessidade em se trabalhar para obter esse alinhamento, sendo necessário manter o foco no que se precisa trabalhar. Isso é, canalizar as energias na direção do objeto ou situação que se deseja ver acontecer.

No capítulo 13 trata sobre a voz fortalecedora. Seria a libertação do talento e da paixão de fazer. Ele nos fala sobre a força inspiradora que há em motivar pessoas em busca de melhoria de seus desempenhos através do envolvimento com aquilo que elas amam. Neste momento, já não é o fazer para ver algo acontecer, mas fazer pelo prazer e pela convicção de que, este fazer trará um bem maior.

No capítulo 14 o autor nos orienta sobre o oitavo hábito de uma maneira geral, apresentando uma espécie de resumo dos capítulos anteriores, na busca da voz interior. Neste caso repete e reforça pontos que acredita devam ser mais realçados.

No capítulo 15, nos fala das questões altruístas desta filosofia de vida, que seria o uso da voz interior com sabedoria, na intenção de servir ao próximo. Neste caso, demonstra a intenção final de sua obra que nos parece ser: a consciência de que, através da transformação do que pensamos sobre nós e nossos propósitos, podermos exercer uma influência transformadora em outras pessoas, de forma a melhorar nossos relacionamentos, nosso trabalho nas organizações e quem sabe, a própria humanidade.

É um livro bem escrito, audacioso e, realmente transformador. Que demonstra que o autor utiliza do próprio encontro com a sua voz interior, para difundir os conhecimentos que o levaram a esse nível de desenvolvimento, às outras pessoas, de forma que essas possam dele se apropriar e encontrar suas vozes interiores.

Tem o desafio maior de tentar mudar paradigmas de gestão mais individualistas e competitivos, calcados em posições rígidas de autoridade e superioridade. Neste lugar, é comum não conseguirem ver o verdadeiro potencial de cada um dos seus subordinados.

Os ensinamentos deste livro trazem a possibilidade de uma maior compreensão sobre a natureza humana e sua capacidade de envolver pelo bom exemplo.

A genialidade está nas propostas sobre ajuda mútua em vez de competitividade; uso da genialidade compartilhada ao invés do medo; paixão e envolvimento ao invés de insegurança.

Em um mundo marcado por intensa competitividade, por descobertas tecnológicas de grande magnitude e pela intensa necessidade de vender e comprar, é preciso um retorno ao humano, de forma a minimizar as frustrações e as desvalorizações humanas, subprodutos dessa corrida desenfreada pelo sucesso. 
Esse novo hábito trás essa possibilidade e mais, a possibilidade real de uma melhoria contínua de nós mesmos. É o caminho do amor, para pessoas que assim desejem encontrá-lo.

Sobre o autor:

1. André Luiz de Albuquerque Farias é Administrador de Empresas e Auditor Federal do Tribunal de Contas da União - TCU. E-mail: farias.andreluiz@gmail.com.

Como citar este artigo (Formato ISO):

FARIAS, A. A. L. O Oitavo Hábito: da eficácia à Grandeza. Resenha. Id on Line Revista de Psicologia, Fevereiro de 2012, vol.1, n.16, p. 28-31. ISSN 1981-1189. 